\title{
GMR
}

\section{Polyandrous behavior in an overexploited giant South American turtle (Podocnemis expansa) population in Central Amazon, Brazil}

\author{
C. Fantin ${ }^{1}$, J. Morais ${ }^{1}$, R. Botero-Arias ${ }^{2}$, C. Araújo ${ }^{2}$, C. Camillo² and \\ I.P. Farias ${ }^{3}$ \\ ${ }^{1}$ Laboratório de Genética Molecular, Mestrado de Biotecnologia, \\ Universidade do Estado do Amazonas, Manaus, AM, Brasil \\ ${ }^{2}$ Instituto de Desenvolvimento Sustentável Mamirauá, Tefé, AM, Brasil \\ ${ }^{3}$ Laboratório de Genética Animal, Universidade Federal do Amazonas, \\ Manaus, AM, Brasil \\ Corresponding author: C. Fantin \\ E-mail: cleitonfantin@hotmail.com
}

Genet. Mol. Res. 16 (1): gmr16019537

Received November 16, 2016

Accepted December 20, 2016

Published February 16, 2017

DOI http://dx.doi.org/10.4238/gmr16019537

Copyright (C) 2017 The Authors. This is an open-access article distributed under the terms of the Creative Commons Attribution ShareAlike (CC BY-SA) 4.0 License.

\begin{abstract}
The aim of the present study was to investigate the reproductive behavior of the giant Amazon River turtle (Podocnemis expansa) in the Amazon. This was carried out by estimating the degree of polymorphism in five DNA microsatellites in a sample of 359 hatchlings from 12 nests in the Mamirauá Sustainable Development Reserve in the municipality of Tefé, state of Amazonas, Brazil. An analysis of allele frequency and variation in the five microsatellite loci allowed for determination of multiple paternity in all nests sampled. Contributions of at least four male turtles to one nest, three male turtles to six nests, and two male turtles to five nests were identified. Knowledge on the reproductive behavior of $P$. expansa can assist in the establishment of management and conservation strategies for the population in the Mamirauá Reserve.
\end{abstract}

Key words: Amazon; Multiple paternity; Podocnemis expansa; Mamirauá; Turtle 


\section{INTRODUCTION}

Multiple paternity stemming from polyandrous behavior has been described for different species, such as the Galapagos hawk (Buteo galapagoensis) (Bollmer et al., 1999), the guppy (Poecilia reticulata) (Evans and Magurran, 2000), and river turtles of the genus Podocnemis (Valenzuela, 2000; Pearse et al., 2006; Fantin et al., 2010). According to Alcock (2011), because more than one male turtle contributes sperm, this behavior offers indirect benefits to female turtles, such as a reduction in the risk of some eggs not becoming fertilized. Promiscuity also enables female turtles to aggregate genes of better quality, with the greater genetic variability improving the viability of the offspring. Compared to single paternity, multiple paternity in some species has important consequences for the increase in the effective population size, which is especially important for endangered species (Lotterhos, 2011).

Two genetic factors are fundamental to a population at risk of extinction. First, gene flow within a population facilitates the dissemination of new alleles obtained through genetic mutations. This enhances the genetic variability and consequently increases the viability in the face of environmental adversity, with improved performance under the pressures of natural selection (Frankham et al., 2010). Second, female turtle mating behavior affects the variability of the offspring, especially when polyandry is combined with multiple paternity (Davy et al., 2011). Together with the ability to store sperm, polyandry allows the genetic variability of the descendants to be temporarily independent of the availability of male turtles. Therefore, polyandrous behavior may be an important reproductive behavior to maximize the genetic diversity of the offspring of long-lived organisms with relatively low fecundity (Davy et al., 2011).

Studies on polyandrous behavior, as described for Podocnemis expansa, report genetic benefits. Together with multiple paternity, this practice increases the genetic variability of the offspring and diminishes the occurrence of inbreeding, which helps restore declining populations (Valenzuela, 2000; Pearse and Avise, 2001). In addition to Podocnemis unifilis and Podocnemis sextuberculata (Fachín-Terán et al., 2000), Podocnemis expansa is categorized on the red list of the International Union for Conservation of Nature (IUCN, 2013) as low risk/dependent on conservation. It is being used for its meat, viscera, and eggs as food sources by local communities and can therefore benefit from the occurrence of multiple paternity in populations with a declining number of individuals.

The population of Podocnemis expansa in the Mamirauá Sustainable Development Reserve in the Brazilian Amazon has undergone a considerable reduction and is practically extinct owing to the high rates of predation in past centuries (Fachín-Terán, 2005). To assist in the conservation of chelonians, the reserve counts on the participation of the surrounding community to protect nesting areas and impede predation by humans and other animals, such as jaguars (Fachín-Terán, 2005; Camillo et al., 2012). However, the current number of spawning female turtles is low, with only 4-12 female turtles laying eggs (Fachín-Terán, 2005). An increase in this number will only be observable after decades of conservation methods (Fachín-Terán, 2005). The Mamirauá Reserve currently has 14 Podocnemis expansa nests on Horizonte Beach, with the hatching of an average of 105 eggs (Fachín-Terán, 2005; Camillo et al., 2012). The aim of the present study was to detect polyandrous behavior in female Podocnemis expansa found in the Mamirauá Reserve, where the species is practically extinct owing to excessive predation by the local community.

Genetics and Molecular Research 16 (1): gmr16019537 


\section{MATERIAL AND METHODS}

\section{Collection of material}

The samples were collected in Mamirauá Sustainable Development Reserve is located in the western Brazilian Amazon between the Japurá, Solimões, and Auti-Paraná Rivers near the municipality of Tefé in the state of Amazonas, Brasil. The reserve is approximately 1,124,000 ha and is entirely situated on floodplains (Fachín-Terán et al., 2003).

Blood samples were taken from 368 individuals: 359 hatchlings from 12 nests and 9 female turtles. Each female turtle pertained to one of nine $P$. expansa nests randomly distributed along the banks of the Solimões River in the Mamirauá Reserve. The nests contained an average of 90 hatchlings, but blood samples were taken from 29 to 30 hatchlings per nest: N1 $=30, \mathrm{~N} 2=30, \mathrm{~N} 3=30, \mathrm{~N} 4=29, \mathrm{~N} 5=30, \mathrm{~N} 6=30, \mathrm{~N} 7=30, \mathrm{~N} 8=30, \mathrm{~N} 9=30, \mathrm{~N} 10=30, \mathrm{~N} 11$ $=30$, and $\mathrm{N} 12=30$. The femoral vein was punctured with a $1-\mathrm{mL}$ syringe for the collection of $100 \mu \mathrm{L}$ blood, which was placed in $2-\mathrm{mL}$ microtubes containing $500 \mu \mathrm{L}$ absolute ethanol and stored at $4^{\circ} \mathrm{C}$. The hatchlings were then released at the site of origin.

\section{DNA extraction}

Genomic DNA was extracted using cetyltrimethylammonium bromide (Doyle and Doyle, 1987), which is adequate for nucleated blood cells and the procedure comprises four steps: cell breakage and removal of proteins/RNA, separation of nucleic acids, precipitation, and hydration of the precipitate. Extraction efficacy and DNA concentration were verified using electrophoresis on $1 \%$ agarose gel. For the gel electrophoresis, $2 \mu \mathrm{L}$ extracted DNA were used with $2 \mu \mathrm{L}$ GelRed $^{\mathrm{TM}}$ stain. After the run, the gel was viewed using an ultraviolet light video data system.

\section{In vitro amplification}

Following extraction, the DNA was subjected to polymerase chain reaction (PCR) by using the cost-effective protocol described by Schuelke (2000). Three primers were used: a specific forward primer sequence with the M13 tail (-21) at the 5' extremity, a specific reverse primer, and a universal M13 sequence (-21) that contained a fluorescent tag (TET or FAM).

The thermal cycling was divided into two steps. First, the forward primer with the M13 (-21) sequence was incorporated into the PCR product. Next, when the forward primer was completely used, the annealing temperature was reduced to allow the annealing of the universal M13 primer (-21) to complement the M13 tail of the forward primer in order to be incorporated into the PCR product with fluorescence. Thus, the amount of forward primer was less than the amount of reverse primer. PCR was performed in a $0.2-\mathrm{mL}$ tube adjusted for a final reaction volume of $13.5 \mu \mathrm{L}$ containing $4.6 \mu \mathrm{L}$ Milli-Q water, $1.5 \mu \mathrm{L} \mathrm{MgCl}_{2}(25 \mathrm{mM}), 1.5 \mu \mathrm{L}$ dNTP mix $(2.5 \mathrm{mM}), 1.5 \mu \mathrm{L}$ Tris- $\mathrm{HCl}(2 \mathrm{mM}), 0.75 \mu \mathrm{L} \mathrm{M} 13$ forward primer $(2 \mathrm{pM} / \mu \mathrm{L}), 0.75 \mu \mathrm{L}$ M13 primer, $1.5 \mu \mathrm{L}$ reverse primer $(2 \mathrm{pM} / \mu \mathrm{L}), 0.4 \mu \mathrm{L}$ Taq polymerase $(1 \mathrm{U} / \mu \mathrm{L})$, and $1.0 \mu \mathrm{L}$ DNA.

The following were the thermal cycling conditions: an initial denaturing temperature of $94^{\circ} \mathrm{C}$ for $2 \mathrm{~min}$; followed by 25 cycles at $94^{\circ} \mathrm{C}$ for $50 \mathrm{~s}, 50^{\circ}-64^{\circ} \mathrm{C}$ (depending on the specific annealing temperature of each primer) for $50 \mathrm{~s}$, and $72^{\circ} \mathrm{C}$ for $1 \mathrm{~min}$; followed by 20 cycles at $94^{\circ} \mathrm{C}$ for $40 \mathrm{~s}, 53^{\circ} \mathrm{C}$ for $35 \mathrm{~s}$, and $72^{\circ} \mathrm{C}$ for $40 \mathrm{~s}$ for annealing of the $\mathrm{M} 13$ primer; and final extension at $72^{\circ} \mathrm{C}$ for $20 \mathrm{~min}$.

Genetics and Molecular Research 16 (1): gmr16019537 
Five microsatellite loci were used for DNA amplification: one described by Sites et al. (1999), two described by Valenzuela (2000) developed for Podocnemis expansa, as well as two described by Fantin et al. (2007) developed for Podocnemis unifilis (Table 1).

Table 1. Microsatellite loci used for used for analyses of Podocnemis expansa.

\begin{tabular}{l|l|c|c|l}
\hline Locus & Repetition & Size $(\mathrm{bp})$ & Annealing temperature $\left({ }^{\circ} \mathrm{C}\right)$ & Reference \\
\hline Pod 91 & $\mathrm{G} 9(\mathrm{GT})_{17}(\mathrm{GA})_{8}$ & $197-247$ & 55 & Sites et al. $(1999)$ \\
\hline PE_344 & $(\mathrm{AG})_{13}$ & $248-298$ & 50 & Valenzuela $(2000)$ \\
\hline PE_519 & $(\mathrm{CT})_{7}(\mathrm{CA})_{18}(\mathrm{CG})_{2}(\mathrm{CA})_{8}$ & $371-455$ & 56 & Valenzuela $(2000)$ \\
\hline Puni_1D12 & $(\mathrm{GA})_{10}$ & $238-292$ & 55 & Fantin et al. $(2007)$ \\
\hline Puni_1E1 & $(\mathrm{CT})_{9} \mathrm{tt}(\mathrm{CT})_{7}$ & $261-301$ & 64 & Fantin et al. (2007) \\
\hline
\end{tabular}

The amplified product was subjected to electrophoresis on $1 \%$ agarose gel in order to determine efficiency of the product. In this procedure, $2 \mu \mathrm{L}$ PCR product were used, to which $2 \mu \mathrm{L} \mathrm{GelRed}{ }^{\mathrm{TM}}$ and a molecular marker of known weight (100 bp) were added for subsequent comparison and the estimation of the concentration of DNA. At the end of the run, the gel was viewed with the aid of an ultraviolet light video data system.

\section{Genotype analysis}

The PCR products were diluted at a proportion of 1:100 and the ROX pUC-19 size marker $(90,105,131,151,182,201,254,306,337,362,425,486,509$, and 560), which was modified from that described by DeWoody et al. (2004), was added. Genotyping was performed in an ABI 3130xl automatic DNA sequencer.

The analysis of alleles for each locus was performed using the GeneMarker v. 2.2.0 program, to identify the genotype of each locus for all individuals sampled. A matrix was then created with information on the genotypes for the statistical analysis of the individuals.

\section{Data analysis}

Probabilities of identity (PI) and exclusion (PE) were calculated for each nest using the GenAlEx 6.501 program (Peakall and Smouse, 2012). For this, an analysis of the frequency of each locus was required, which was determined using the Arlequin 3.5.1.3 program (Excoffier and Lischer, 2010). PI and PE range from 0 to 1 and indicate the extent to which a locus is informative. PI values closer to 0 and $\mathrm{PE}$ values closer to 1 indicate a more informative locus.

The simple allele count method (Myers and Zamudio, 2004) was used for the paternity analysis, which presupposes Mendelian distribution of the alleles in a brood. In this method, the presence of five alleles per locus among the hatchlings in each nest is considered indicative of multiple paternity when no maternal allele is known (two maternal alleles, two alleles from one male turtle, and one from another male turtle). The analysis of paternity was also based on the inference of maternal genotypes, which were identified by the presence of hatchlings per nest that were homozygous for one or more loci. A maternal allele can be inferred when a hatchling is homozygous for a given locus (AA) and the complete maternal genotype can be inferred when the hatchling is homozygous for two different alleles (AA and BB; maternal genotype: $\mathrm{AB}$ ). When a maternal allele can be inferred, multiple paternity is estimated for a nest if the analysis of a locus indicates four alleles. If two maternal alleles can be detected, the presence of three alleles in the locus analyzed indicates multiple paternity in the nest.

Genetics and Molecular Research 16 (1): gmr16019537 
Other genotype analyses were also used. The Kinalyzer program (Berger-Wolf et al., 2007; Ashley et al., 2009) was used to estimate relationships between true and half siblings in the same brood, as well as to attribute paternity and infer the mating system (polygamous or monogamous) with no knowledge of the maternal genotype. This program uses combinatory optimization based on the rules of Mendelian inheritance to find the smallest number of sibling groups that contain all individuals. The GERUD 2.0 program (Jones, 2005) was used to confirm the maternal genotype of the nests. This program reconstructs the parental genotypes and allows the identification of the minimum number of male contributors based on the genotypes of the offspring.

Excess homozygotes lead to a deviation of the population from the Hardy-Weinberg equilibrium. However, homozygosity may be apparent when an allele is not detected for some reason. This apparent homozygosis may occur owing to null alleles or non-amplified alleles. For microsatellites, null alleles are the result of degradation, low DNA concentrations, or a mutation in the flanking regions, which impede the recognition and annealing of the primers. The analysis of the occurrence of null alleles was performed with the aid of the Micro-Checker 2.2.3 program (Oosterhout et al., 2004), which consists of an application developed to seek null alleles, stutter bands, and drop-out alleles that occur during the PCR process and can affect the microsatellite analysis.

\section{RESULTS}

A total of 359 hatchlings and 9 female turtles from 12 Podocnemis expansa nests were genotyped based on five microsatellite loci. The number of alleles per locus ranged from 21 to 37. Observed heterozygosis ranged from 0.3152 (Pod_91) to 0.9599 (Puni_1D12) (Table 2). Observed heterozygosis in the combination of all loci was $99.99 \%$, indicating a high degree of sensitivity of the five loci analyzed regarding the detection of multiple paternity in this species. PI and PE values ranged from 0.0291 (Pe_344) to 0.0773 (Pod_91) and from 0.9445 (Puni_1E1) to 0.9731 (Pod_91), respectively (Table 2).

Table 2. Number of alleles $\left(N_{\mathrm{A}}\right)$, observed heterozygosis $\left(H_{\mathrm{O}}\right)$, expected heterozygosis $\left(H_{\mathrm{E}}\right)$, probability of identification (PI), and probability of exclusion of paternity (PE) for five microsatellite loci used in an analysis of multiple paternity in Podocnemis expansa.

\begin{tabular}{l|c|c|c|c|c|c}
\hline Locus & $N_{\mathrm{A}}$ & $H_{\mathrm{O}}$ & $H_{\mathrm{E}}$ & PI & PE & Reference \\
\hline Pod 91 & 26 & 0.3152 & 0.9399 & 0.0773 & 0.9731 & Sites et al. (1999) \\
\hline Pe_344 & 25 & 0.7951 & 0.9304 & 0.0291 & 0.9654 & Valenzuela $(2000)$ \\
\hline Pe_519 & 37 & 0.3921 & 0.9340 & 0.0469 & 0.9699 & Valenzuela (2000) \\
\hline Puni_1D12 & 25 & 0.9599 & 0.9194 & 0.0376 & 0.9524 & Fantin et al. (2007) \\
\hline Puni_1E1 & 21 & 0.5274 & 0.9068 & 0.0413 & 0.9445 & Fantin et al. (2007) \\
\hline Mean & 26.8 & 0.5979 & 0.9261 & $* 1.09 \mathrm{E}-07$ & $* 0.9999$ & \\
\hline
\end{tabular}

*Probability of identity and exclusion of paternity of combined loci.

The simple allele counts per locus indicated multiple paternity in all nests except N1, in which locus Pod_91 only had four alleles (Table 3). Known maternal genotypes in nests from which samples from female turtles were taken and inferred maternal genotypes based on homozygous hatchlings showed multiple paternity, with the contribution of at least two male turtles to each brood. 
Table 3. Number of alleles per locus in 12 analyzed nests; minimum inference of fathers based on number of alleles per locus; minimum number of sibling groups estimated using Kinalyzer; and minimum number of fathers inferred using GERUD 2.0.

\begin{tabular}{|c|c|c|c|c|c|c|c|c|}
\hline \multirow[t]{2}{*}{ Nest } & \multicolumn{5}{|c|}{ Locus } & \multirow{2}{*}{ Minimum inference of fathers } & \multirow[t]{2}{*}{ Kinalyzer } & \multirow[t]{2}{*}{ GERUD 2.0} \\
\hline & Pod 91 & Pe 344 & Pe 519 & Puni 1D12 & Puni 1E1 & & & \\
\hline N1* & 4 & 13 & 16 & 15 & 10 & 1 & 15 & 2 \\
\hline $\mathrm{N} 2 *$ & 8 & 16 & 13 & 16 & 7 & 3 & 13 & 3 \\
\hline N3* & 12 & 10 & 13 & 17 & 9 & 4 & 14 & 3 \\
\hline $\mathrm{N} 4 *$ & 9 & 17 & 11 & 15 & 13 & 4 & 14 & 2 \\
\hline N5* & 9 & 18 & 10 & 12 & 13 & 4 & 14 & 3 \\
\hline N6* & 10 & 9 & 7 & 10 & 12 & 3 & 13 & 3 \\
\hline N7* & 10 & 12 & 11 & 11 & 12 & 4 & 14 & 2 \\
\hline N8* & 8 & 12 & 23 & 8 & 6 & 2 & 14 & 4 \\
\hline N9* & 13 & 14 & 8 & 8 & 14 & 3 & 13 & 2 \\
\hline N10 & 15 & 13 & 8 & 9 & 8 & 3 & 12 & 2 \\
\hline N11 & 8 & 6 & 14 & 5 & 11 & 2 & 12 & 3 \\
\hline N12 & 10 & 13 & 10 & 10 & 13 & 4 & 13 & 3 \\
\hline
\end{tabular}

*Nest with known maternal genotype.

The formation of sibling groups through optimization performed using Kinalyzer indicated the occurrence of 12 (N10 and N11), 13 (N2, N6, N9, and N12), 14 (N3, N4, N5, N7, and N8), and 15 (N1) groups, based on the combined analysis of all loci (Table 3). Moreover, GERUD 2.0 enables the simulation of maternal and paternal genotypes for each brood. A comparison between the simulated maternal genotypes and the genotypes of the analyzed female turtles showed the same pattern for all loci except two female turtles that were homozygous for some loci. The simulation of paternal genotypes enabled estimating the minimum number of male contributors to each brood, indicating a minimum of two (N1, N4, N7, N9, and N10), three (N2, N3, N5, N6, N11, and N12), and four (N8) fathers (Table 3).

The analysis of null alleles in the genotypes, performed using Micro-Checker 2.2.3, showed significant frequencies in all loci. However, only Pod_91 showed significant null allele frequencies in all nests, whereas Pe 519 and Puni_1E1 showed significant null allele frequencies in all but one nest each (N2 and N4, respectively). Pe 344 exhibited significant null frequencies in three nests (N1, N7, and N11) and Puni_1D12 exhibited a significant null frequency in only one nest (N2) (Table 4). The presence of null alleles stemming from a mutation in the annealing region of the primers impedes the amplification of the allele. Thus, a homozygote result represents the amplification of only one allele.

Table 4. Frequency of null alleles in nest analysis of loci Pod_91, Pe_344, Pe_519, Puni_1E1, and Puni_1D12, generated using Micro-Checker program; $(-)=$ absence of significant frequency of null alleles.

\begin{tabular}{l|c|c|c|c|c}
\hline \multirow{2}{*}{ Nest } & \multicolumn{3}{c}{ Locus } & Puni_1D12 & Puni_1E1 \\
\cline { 2 - 6 } & Pod_91 & Pe_344 & Pe_519 & - & 0.2282 \\
\hline N1 & 0.3459 & 0.2743 & -1618 & 0.0988 & 0.1567 \\
\hline N2 3 & 0.4703 & - & - & - & 0.0936 \\
\hline N4 & 0.3568 & - & 0.2355 & - & - \\
\hline N6 & 0.4492 & - & 0.2040 & - & 0.1008 \\
\hline N7 & 0.2934 & - & 0.4760 & - & 0.3787 \\
\hline N8 & 0.3755 & 0.1255 & 0.0957 & - & 0.0888 \\
\hline N10 & 0.1808 & - & 0.4290 & - & 0.3734 \\
\hline N11 & 0.1391 & - & 0.4514 & - & 0.3146 \\
\hline N12 & 0.3091 & - & 0.2019 & & - \\
\hline & 0.1660 & 0.1795 & 0.4729 & -0978 & 0.2526 \\
\hline
\end{tabular}

Genetics and Molecular Research 16 (1): gmr16019537 


\section{DISCUSSION}

The five loci used for the paternity analysis of Podocnemis expansa showed satisfactory polymorphic patterns in the loci specifically developed for this species (Pod_91, Pe_344, and Pe 519), as well as in those initially developed for Podocnemis unifilis (Puni_1D1 $\overline{2}$ and Puni_1E1). The high degree of polymorphism in these loci is of extreme importance, as the information contained in each locus, which directly depends on the number of alleles and distribution of allelic frequencies, potentiates the sensitivity of the paternity assessment (Wenk et al., 2005).

The efficacy of the paternity analysis does not depend on the number of loci used, but rather on their informative power, which is evidenced by the PI and PE of paternity (Curi and Lopes, 2001). In the present study, the five analyzed loci had satisfactory PI ( 0.0073 to 0.0158$)$ and PE (0.9445 to 0.9731) indices. A low PI and a high PE of paternity indicate considerable informative value of these loci. Pearse et al. (2006) also analyzed multiple paternity in Podocnemis expansa and found good PE indices using the primers developed by Sites et al. (1999) and Valenzuela (2000) (Pod_91 and Pe_519). These primers were confirmed as being sufficiently sensitive for the detection of multiple paternity in the present investigation.

The simple allele count method presupposes a Mendelian distribution of the alleles in the brood, as each hatchling should inherit two maternal alleles and one paternal allele. With this method, all alleles in the hatchlings that are not inherited from the female turtle are necessarily acquired through the genotype of the fathers (Myers and Zamudio, 2004). Thus, the occurrence of more than two alleles beyond the maternal alleles indicates multiple paternity in the offspring. Although informative, this method does not enable estimating the minimum number of male contributors to each nest. Such information can obtained using GERUD 2.0 (Jones, 2005), which allows for simulating the parental genotypes and estimating the minimum number of male contributors to each brood with the five loci combined. A $100 \%$ rate of multiple paternity was found in the nests analyzed in this study, based on simple allele counts. This rate was confirmed by the analysis using GERUD 2.0, which indicated two to four male contributors to each brood.

Valenzuela (2000) found multiple paternity in two nests analyzed from a Podocnemis expansa population in the Caquetá River in Colombia, using eight microsatellite loci. The analyses revealed the contribution of at least two male turtles in one nest and three in the other. In contrast, Pearse et al. (2006) found multiple paternity in only $10.3 \%$ of the broods of 32 nests in a population on the Orinoco River in Venezuela, using seven microsatellite loci. This divergence between the two studies demonstrates that populations in different locations may exhibit different paternity patterns. It also indicates that the sample size is relevant when determining whether polyandrous reproductive behavior is predominant in a population.

Multiple paternity has been reported in other species of the genus Podocnemis. Fantin et al. (2008) found multiple paternity in six nests of a Podocnemis unifilis population on the Amazon River (municipality of Barreirinha, state of Amazonas, Brazil) using eight microsatellite loci, demonstrating the contribution of at least two male turtles to each brood. Freda et al. (2016) also found multiple paternity in seven Podocnemis sextuberculata nests on the Amazon River by using six microsatellite loci, demonstrating at least two male contributors to each brood. In another study, Fantin et al. (2010) analyzed six Podocnemis erythrocephala nests by using four microsatellite loci and found the participation of more than two male turtles.

Genetics and Molecular Research 16 (1): gmr16019537 
The multiple paternity rate in the present study is, thus, in agreement with data reported in previous studies, in which Podocnemis expansa was found to be a species with polyandrous reproductive behavior (Valenzuela, 2000; Pearse et al., 2006). This behavior has also been reported as predominant in other reptiles, such as crocodilians (Oliveira et al., 2010), lizards (Oppliger et al., 2007), snakes (Madsen et al., 2005), and chelonians (Pearse et al., 2002; Roques et al., 2006; Fantin et al., 2008; Fantin et al., 2010; Freda et al., 2016). Although polyandry occurs in a large part of the reptile group, it is intriguing that the female turtles do not derive direct benefits from this behavior. The advantages are suggested to be indirect, in the form of genetic contribution and fertilization of the eggs, even though there is not sufficient evidence to prove these advantages (Pearse and Avise, 2001; Uller and Olsson, 2008). The most obvious indirect benefit to the female turtle is the fertilization of her eggs, which is of extreme importance to the giant Amazon River turtle, as an average of more than 100 eggs are produced per female turtle during the reproductive season (Pearse and Avise, 2001; Vogt, 2008).

According to Jennions and Petrie (2000), genetic benefits favor the genetic diversity of the offspring, by reducing genetic incompatibility between male and female turtles in a population. The occurrence of inbreeding is thereby diminished, whereas the viability of the offspring increases in the face of environmental diversity, by improving performance under natural selection pressures (Jennions and Petrie, 2000). In populations that have declined due to environmental pressure, genetic variability is necessary to avoid local extinction (Frankham et al., 2010).

Studies on the effective population size are important to understand the evolutionary pressures that affect populations. The main aspect of the discussion is whether polygamous behavior on the part of female turtles results in a larger effective population size in comparison to monogamy (Karl, 2008; Lotterhos, 2011). According to Karl (2008), reproductive behavior is not sufficient to benefit the effective size of a population and other factors of the reproductive system have greater importance. However, analyzing groups with monogamous and polygamous behavior, Lotterhos (2011) found that polyandrous female turtles had greater reproductive success than monogamous female turtles.

Populations at risk of extinction could be favored by polyandrous behavior, which allows an increase in genetic variability and a consequent increase in the effective size of the population. The giant Amazon River turtle has been considered ecologically extinct from the Mamirauá Reserve, due both to considerable predation in past centuries and the low current number of spawning female turtles (only four to 12 laying eggs) (Fachín-Terán, 2005). In the 1990 s, nesting areas began to be protected on different beaches of the reserve by the local community, thereby allowing an increase in the successful hatching of turtles. However, an increase in the number of Podocnemis expansa female turtles spawning on protected beaches will only be detectable after decades of conservation measures directed at the species (FachínTerán, 2005).

In the present study, multiple paternity was found in $100 \%$ of the nests analyzed. This is a sign of the recovery of the giant Amazon River turtle population in the Mamirauá Reserve, as polyandrous reproductive behavior exerts a direct influence on the genetic variability of the offspring and an increase in the number of fertilized eggs. Understanding the reproductive behavior of a given species is of extreme importance, as this behavior affects the genetic profile of the population. Such knowledge can contribute to the establishment of management and conservation strategies directed at Podocnemis expansa.

Genetics and Molecular Research 16 (1): gmr16019537 


\section{Conflicts of interest}

The authors declare no conflict of interest.

\section{ACKNOWLEDGMENTS}

This study is part of the Amazon Aquatic Vertebrate Conservation Project (Aquavert) developed by the Mamirauá Sustainable Development Institute and sponsored by Petrobrás through the Petrobrás Environmental Program. Funding was provided by the following Brazilian fostering agencies: Conselho Nacional de Desenvolvimento Científico e Tecnológico $(\mathrm{CNPq})$ and Fundação de Apoio à Pesquisa do Estado do Amazonas (FAPEAM).

\section{REFERENCES}

Alcock J (2011). Comportamento animal - Uma abordagem evolutiva. 9th edn. Artmed, Porto Alegre.

Ashley MV, Caballero IC, Chaovalitwongse W, Dasgupta B, et al. (2009). KINALYZER, a computer program for reconstructing sibling groups. Mol. Ecol. Resour. 9: 1127-1131. http://dx.doi.org/10.1111/j.1755-0998.2009.02562.x

Berger-Wolf TY, Sheikh SI, DasGupta B, Ashley MV, et al. (2007). Reconstructing sibling relationships in wild populations. Bioinformatics 23: i49-i56. http://dx.doi.org/10.1093/bioinformatics/btm219

Bollmer JL, Irwin ME, Rieder JP and Parker PG (1999). Multiple paternity in loggerhead turtle clutches. Copeia 1999: 475-478. http://dx.doi.org/10.2307/1447494

Camillo CS, Santos OM, Sousa I and Queiroz HL (2012). Community-based freshwater turtle conservation in middle Solimões River, AM, Brazil. Uakari 8: 35-44.

Curi RA and Lopes CR (2001). Teste de paternidade em bovinos. Biotecnolog. Cienc. Desenvolv. 21: 40-45.

Davy CM, Edwards T, Lathrop A, Bratton M, et al. (2011). Polyandry and multiple paternities in the threatened Agassiz's desert tortoise. Gopherusagassizii. Conserv. Genet 12: 1313-1322. http://dx.doi.org/10.1007/s10592-011-0232-y

DeWoody JA, Schupp J, Kenefic L, Busch J, et al. (2004). Universal method for producing ROX-labeled size standards suitable for automated genotyping. Biotechniques 37: 348-352, 350, 352.

Doyle JJ and Doyle JL (1987). Isolation of plant DNA from fresh tissue. Focus 12: 13-15.

Evans JP and Magurran AE (2000). Multiple benefits of multiple mating in guppies. Proc. Natl. Acad. Sci. U. S. A. 97: 10074-10076.

Excoffier L and Lischer HEL (2010). Arlequin suite ver 3.5: a new series of programs to perform population genetics analyses under Linux and Windows. Mol. Ecol. Resour. 10: 564-567. http://dx.doi.org/10.1111/j.1755-0998.2010.02847.x

Fachín-Terán A (2005). Participação comunitária na preservação de praias para reprodução de quelônios na reserva de desenvolvimento sustentável mamirauá, amazonas, Brasil. Uakari 1: 19-30.

Fachín-Terán A, Vogt RC and Thorbjarnarson JB (2000). Padrões de caça e uso de quelônios na Reserva de Desenvolvimento Sustentável Mamirauá, Amazonas, Brasil. Manejo de Fauna Silvestre en Amazonía y Latinoamérica (Cabrera E, Mercolli C and Resquin R, eds.). Asunción, 232-337.

Fachín-Terán A, Vogt RC and Thorbjarnarson JB (2003). Estrutura populacional, razão sexual e abudância de Podocnemis sextuberculata (Testudines, Podocnemididae) na Reserva de Desenvolvimento Sustentável Mamirauá, Amazonas, Brasil. Phyllomedusa 2: 43-63. http://dx.doi.org/10.11606/issn.2316-9079.v2i1p43-63

Fantin C, Carvalho CF, Hrbek T, Sites Jr JW, et al. (2007). Microsatellite DNA markers for Podocnemis unifilis, the endangered yellow-spotted Amazon River turtle. Mol. Ecol. Notes 7: 1235-1238. http://dx.doi.org/10.1111/j.1471$\underline{8286.2007 .01842 . x}$

Fantin C, Viana LS, Monjeló LAS and Farias IP (2008). Polyandry in Podocnemis unifilis (Pleurodira: Podocnemididae), the vulnerable yellow-spotted Amazon River turtle. Amphib.-reptil. 29: 479-486. http://dx.doi. org/10.1163/156853808786230361

Fantin C, Farias IP, Monjeló LAS and Hrbek T (2010). Polyandry in the red-headed river turtle Podocnemis erythrocephala (Testudines, Podocnemididae) in the Brazilian Amazon. Genet. Mol. Res. 9: 435-440. http://dx.doi.org/10.4238/ vol9-1gmr749

Frankham R, Ballou JD and Briscoe DA (2010). Introduction to conservation genetics. 2nd ed. Cambridge University Press, Cambridge.

Genetics and Molecular Research 16 (1): gmr16019537 
Freda FP, Bernardes VC, Eisemberg CC, Fantin C, et al. (2016). Relationship between multiple paternity and reproductive parameters for Podocnemis sextuberculata (Testudines: Podocnemididae) in the Trombetas River, Brazil. Genet. Mol. Res. 15: http://dx.doi.org/10.4238/gmr.15017335.

IUCN (2013). IUCN Red List of Threatened Species. Version 2013. Available at [www.iucnredlist.org]. Accessed February 10, 2015.

Jennions MD and Petrie M (2000). Why do females mate multiply? A review of the genetic benefits. Biol. Rev. Camb. Philos. Soc. 75: 21-64. http://dx.doi.org/10.1017/S0006323199005423

Jones AG (2005). GERUD 2.0: A computer program for the reconstruction of parental genotypes from half-sib progeny arrays with known or unknown parents. Mol. Ecol. Notes 5: 708-711. http://dx.doi.org/10.1111/j.1471$\underline{8286.2005 .01029 . \mathrm{x}}$

Karl SA (2008). The effect of multiple paternity on the genetically effective size of a population. Mol. Ecol. 17: 39733977. http://dx.doi.org/10.1111/j.1365-294X.2008.03902.x

Lotterhos KE (2011). The context-dependent effect of multiple paternity on effective population size. Evolution 65: 1693 1706. http://dx.doi.org/10.1111/j.1558-5646.2011.01249.x

Madsen T, Ujvari B, Olsson M and Shine R (2005). Paternal alleles enhance female reproductive success in tropical pythons. Mol. Ecol. 14: 1783-1787. http://dx.doi.org/10.1111/j.1365-294X.2005.02505.x

Myers EM and Zamudio KR (2004). Multiple paternity in an aggregate breeding amphibian: the effect of reproductive skew on estimates of male reproductive success. Mol. Ecol. 13: 1951-1963. http://dx.doi.org/10.1111/j.1365294X.2004.02208.x

Oliveira DP, Farias IP, Marioni B, Campos Z, et al. (2010). Microsatellite markers for mating system and population analyses of the spectacled caiman Caiman crocodilus (Linnaeus 1758). Conserv. Genet. Resour. 2: 181-184. http:// dx.doi.org/10.1007/s12686-010-9221-6

Oosterhout CV, Hutchinson WF, Wills DPM and Shipley P (2004). MICRO-CHECKER: software for identifying and correcting genotyping errors in microsatellite data. Mol. Ecol. Notes 4: 535-538. http://dx.doi.org/10.1111/j.14718286.2004.00684.X

Oppliger A, Degen L, Bouteiller-Reuter C and John-Alder HB (2007). Promiscuity and high level of multiple paternity in common wall lizards, Podarcis muralis: data from microsatellite markers. Amphib.-reptil. 28: 301-303. http://dx.doi. org/10.1163/156853807780202477

Peakall R and Smouse PE (2012). GenAlEx 6.5: genetic analysis in Excel. Population genetic software for teaching and research--an update. Bioinformatics 28: 2537-2539. http://dx.doi.org/10.1093/bioinformatics/bts460

Pearse DE and Avise JC (2001). Turtle mating systems: behavior, sperm storage, and genetic paternity. J. Hered. 92: 206211. http://dx.doi.org/10.1093/jhered/92.2.206

Pearse DE, Janzen FJ and Avise JC (2002). Multiple paternity, sperm storage, and reproductive success of female and male painted turtles (Chrysemys picta) in nature. Behav. Ecol. Sociobiol. 51: 164-171. http://dx.doi.org/10.1007/ $\underline{\text { s00265-001-0421-7 }}$

Pearse DE, Dastrup RB, Hernandez O and Sites Jr JW (2006). Paternity in an Orinoco population of endangered Arrau River turtles, Podocnemis expansa (Pleurodira, Podocnemididae), from Venezuela. Chelonian Conserv. Biol. 5: 232238. http://dx.doi.org/10.2744/1071-8443(2006)5[232:PIAOPO]2.0.CO;2

Roques S, Diaz-Paniagua C, Portheault A, Pérez-Santiagosa N, et al. (2006). Sperm storage and low incidence of multiple paternity in the European pond turtle, Emys orbicularis: a secure but costly strategy? Biol. Conserv. 129: 236-243. http://dx.doi.org/10.1016/j.biocon.2005.10.039

Schuelke M (2000). An economic method for the fluorescent labeling of PCR fragments. Nat. Biotechnol. 18: 233-234. http://dx.doi.org/10.1038/72708

Sites JW, Fitzsimmons NN, Da Silva JN and Cantarelli VH (1999). Conservation genetics of the giant Amazon River turtle (Podocnemis expansa, Pelomedusidae) - inferences from two classes of molecular markers. Chelonian Conserv. Biol. 3: 454-463.

Uller T and Olsson M (2008). Multiple paternity in reptiles: patterns and processes. Mol. Ecol. 17: 2566-2580. http:// dx.doi.org/10.1111/j.1365-294X.2008.03772.x

Valenzuela N (2000). Multiple paternity in side-neck turtles Podocnemis expansa: evidence from microsatellite DNA data. Mol. Ecol. 9: 99-105. http://dx.doi.org/10.1046/j.1365-294x.2000.00806.x

Vogt RC (2008). Tartarugas da Amazônia. 1st ed. Gráfica Biblos, Lima.

Wenk RE, Gjertson DW, Chiafari FA and Houtz T (2005). The specific power of parentage exclusion in a child's blood relatives. Transfusion 45: 440-444. http://dx.doi.org/10.1111/j.1537-2995.2005.04271.x

Genetics and Molecular Research 16 (1): gmr16019537 